\title{
ИСТОРИЯ РАЗВИТИЯ, ИСТОРИЧЕСКИЕ АСПЕКТЫ И СОВРЕМЕННОЕ СОСТОЯНИЕ ПРОБЛЕМЫ РЕАБИЛИТАЦИИ ПАЦИЕНТОВ С ВРОЖДЁННОЙ РАСЩЕЛИНОЙ ЛИЦА
}

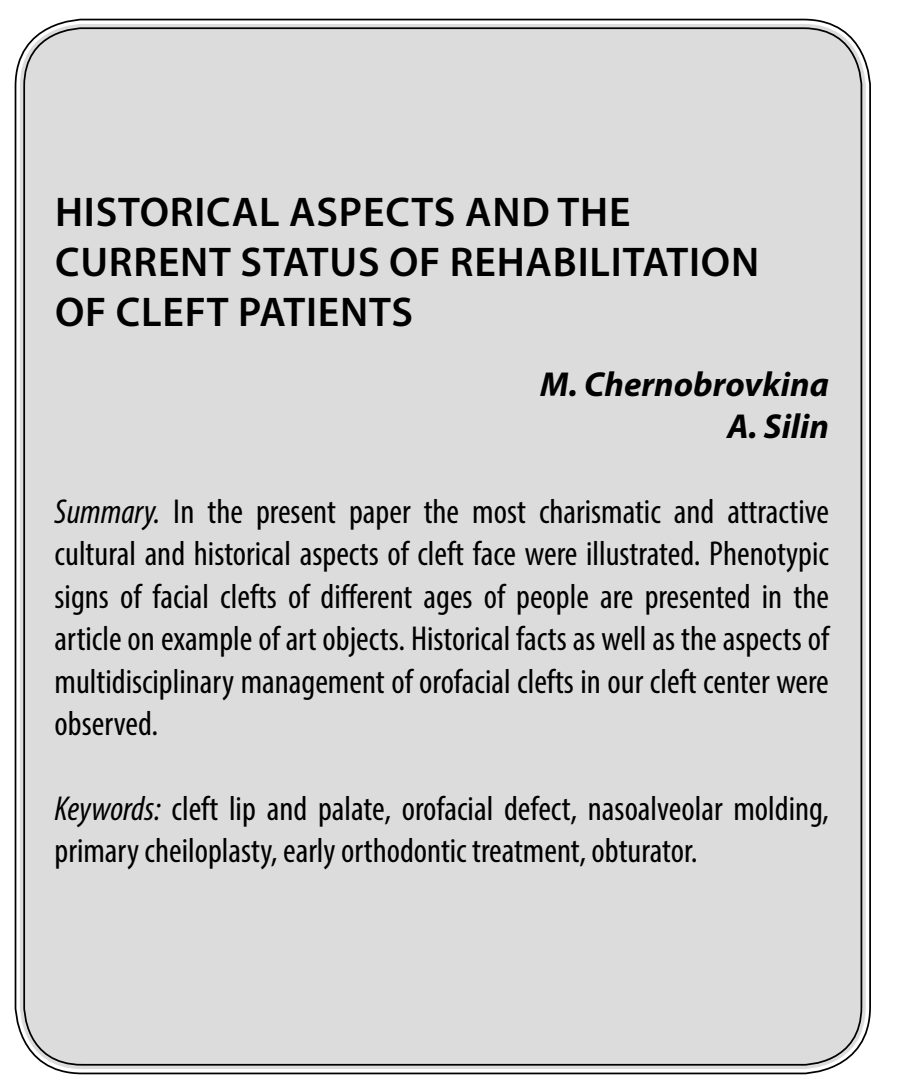

«Девять десятых нашего

счастья зависит от здоровья»

Артур Шопенгауэр

\section{Введение}

$\square$ моционально-чувственное восприятие эстетики человеческого лица невольно моделирует в сознании каждого человека его субъективный образ о степени внутренней красоты личности, уровне интеллекта, социальном статусе, его общественной популярности и признательности в социуме. В рамах маркетинга канонов современной красоты культивируется представление об успешном и привлекательном индивидууме и бессознательно стигматизируют людей, внешний вид которых отличается от гармоничных пропорций. В масштабных отечественных и зарубежных исследованиях подробно изучена и широко раскрыта проблема травматизирующего влияния нежелательных
Чернобровкина Мария Игоревна

К.м.н., ФГБОУ ВО «Северо-Западный государственный медицинский университет имени И.И. Мечникова» Министерства здравоохранения Российской Федерации tchernobrovik@mail.ru

Силин Алексей Викторович

Д.м.н., профессор, ФГБОУ ВО «Северо-Западный государственный медицинский университет имени

И.И. Мечникова» Министерства здравоохранения Российской Федерации silin@me.com

Аннотация. В статье представлен исторический экскурс в проблему социального восприятия врождённых аномалий развития лица, и развитие концепций комплексного лечения и реабилитации пациентов с подобными дефектами. На примере наиболее интересных и ярких предметов искусства и архитектуры описаны фенотипические особенности проявлений расщелин лица у лиц разного возраста и пола. Статья знакомит читателя с аспектами работы междисциплинарной команды врачей специализированного диспансерного центра для детей с врождёнными аномалиями развития тканей челюстно-лицевой области Санкт-Петербурга.

Ключевые слова: врождённая расщелина лица, аномалии лица, деформации лица, обтуратор, раннее ортодонтическое лечение, первичная хейлоринопластика.

вопросов со стороны окружающего социума об особенностях внешности и речи детей, родившихся с орофациальным дефектом.

\section{Расшелина лича в искусстве}

История понимания, развития фундаментальных знаний о возможностях достижения успешного лечения врождённых дефектов лица претерпела значительные изменения в представлениях от «божьей кары» до создания высокотехнологичных алгоритмов комплексной медицинской реабилитации пациентов с расщелинами лица.

В 18 веке в Кунсткамере совместно с профессором анатомии из Амстердама Фредериком Рюйшем Пётр I создали уникальную естественное-научную тератологическую коллекцию препаратов, большая часть которых включала известные формы врождённых расщелин лица, с единственной целью - распространить знания 


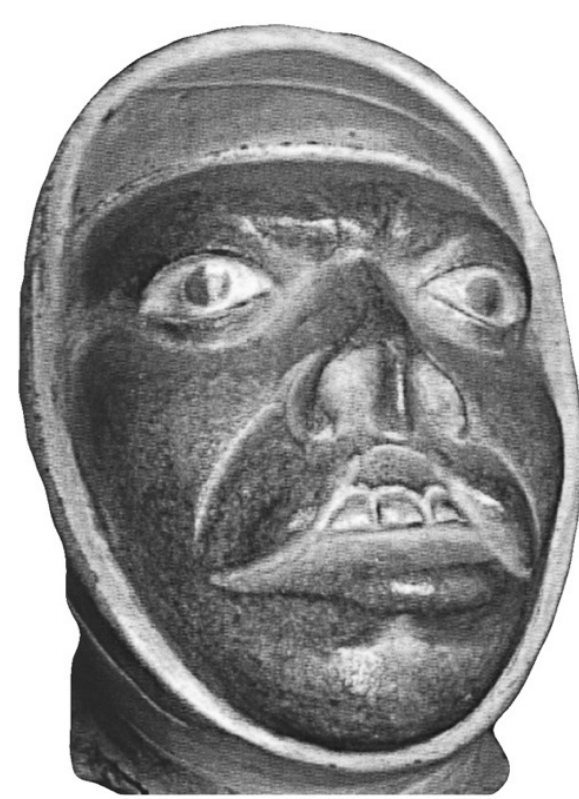

Рис. 1. Лицо с врождённой расщелиной лица, сочетанной с синдромом Пьера Робена культуры Моче в Перу

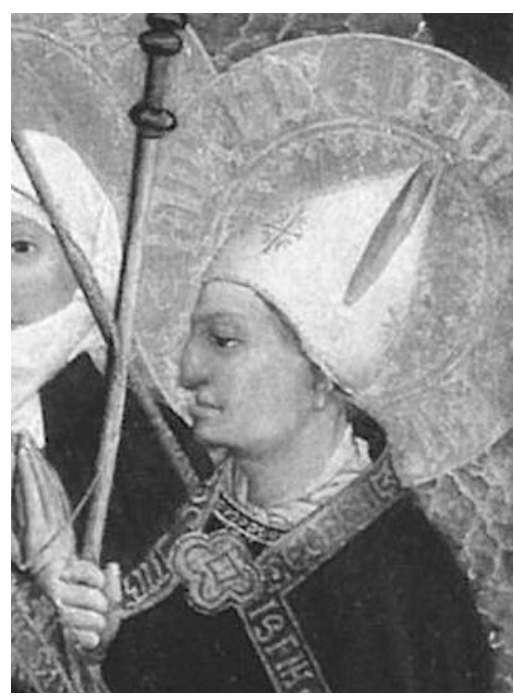

Рис. 3. Сюжет Тифенброннского алтаря Святой Магдалины Лукаса Мозера (1431 год)

в первую очередь среди людей науки, а потом и среди непросвещённого люда, ложно уверовавшего, что отклонения в развитии здоровья происходят от «действа дьявольского чрез ведовство и порчу».

Древняя и развитая цивилизация близ современного города Южной Америки Лимы - Моче (I—VIII века н.э.), которая по праву считается значительнее древнее Ин-

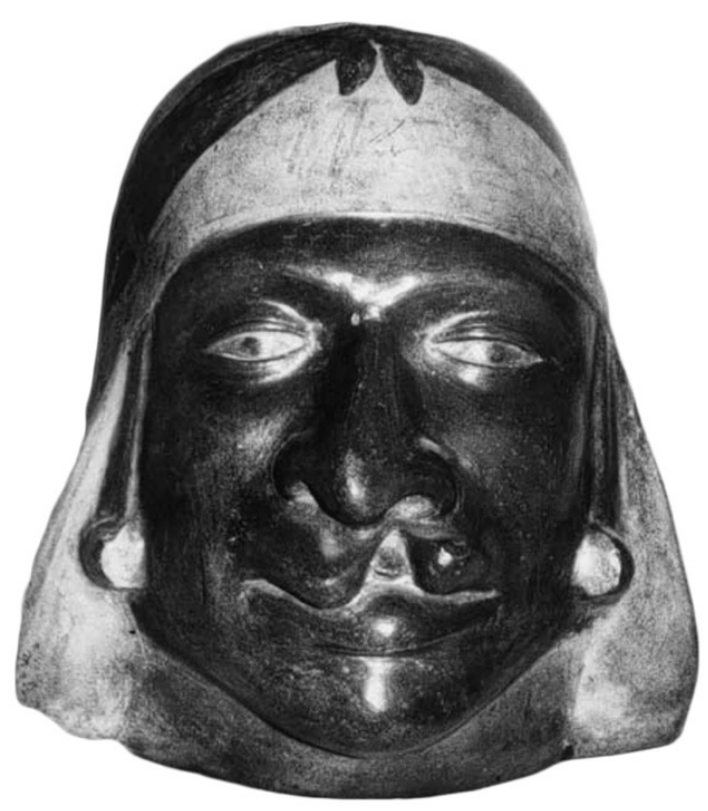

Рис. 2. Лицо мужчины с левосторонней врождённой расщелиной лица культуры Ламбайек-Сикан

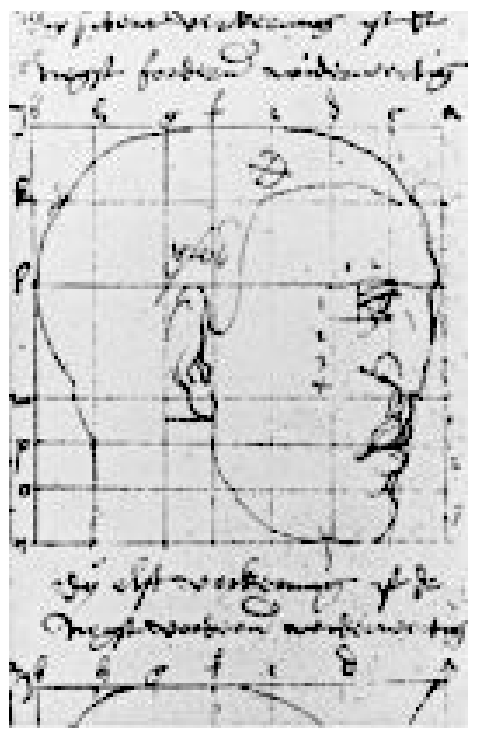

Рис. 4. Эскиз Леонардо да Винчи (около 1485-1490)

ков, не имела своей письменности, зато в деталях предоставила доподлинно запечатленные в камне и керамике изображения лица с врождённой расщелиной лица, которые прекрасно сохранились до наших дней [5]. Одно из лиц, написанное в камне, с предельной выразительностью передаёт лицо мужчины благородного происхождения, на левой стороне лица которого присутствует полная расщелина лица (рис. 1). Богатая культура камен- 


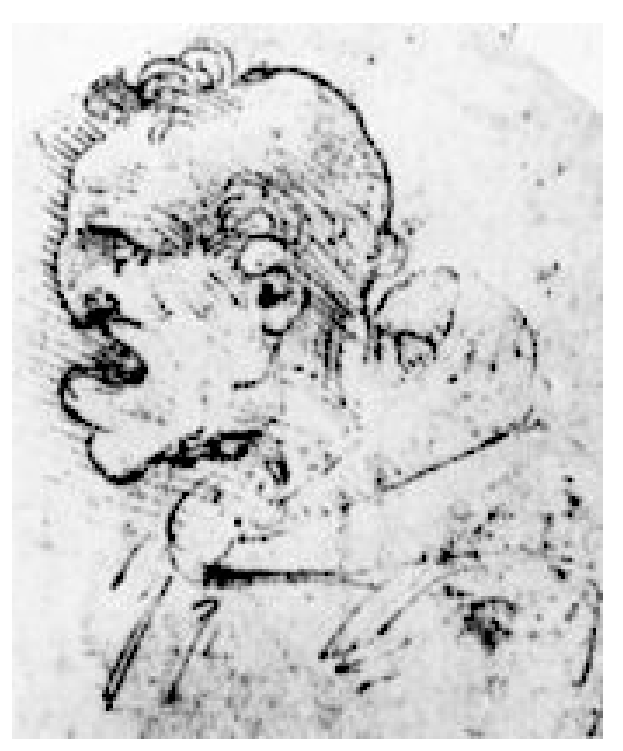

Рис. 5. Эскиз Альбрехта Дюрера из труда «Сконструированные фигуры и головы» ных изваяний подарила множество изысканных и реалистичных керамических статуй культуры Ламбайек-Сикан (750-1100 н.э.) из других регионов Перу, Южной и Центральной Америки, изображавших одно- и двусторонние врождённые расщелины лица [10] у людей самых разных возрастов (рис. 2). Особое высокогорное положение указанных цивилизаций значительно коррелирует с высокой частотой рождения детей с расщелиной лица в связи с развивающейся хронической гипоксией плода [7].

На одном из «самых известных в мире и великолепных алтарей Святой Магдалины» в Тифенбронне, созданный мастером Лукасом Мозером, первой половины 15 века, представлен сюжет о путешествии пяти святых - Мария, Лазарь, Марфа, Максимилиан и Гедониус. Святой Гедониус с самого рождения был слеп и был чудодейственно исцелен Христом за свои деяния [6]. Алтарный сюжет ярко изображает лицо святого в профиль с его левой стороны, причём его внешний облик насыщенно отражает выразительные черты человека уже после хирургического вмешательства, проведённого по поводу врождённой расщелины лица: укорочение и уплощение верхней губы, укорочение колумеллы носа, нарушение роста и развития верхней челюсти в сагиттальной плоскости.

Художники Ренессанса Леонардо да Винчи и Альбрехт Дюрер в своих трудах не только реалистично воссоздают лица людей, имеющих врождённую расщелину лица, но и формируют цельную математическую модель лица при помощи точного расчёта гармонии численных отношений и пропорций тела и лица человека (рис. 4 и рис. 5). Даже сейчас по трактатам этих великих худож-

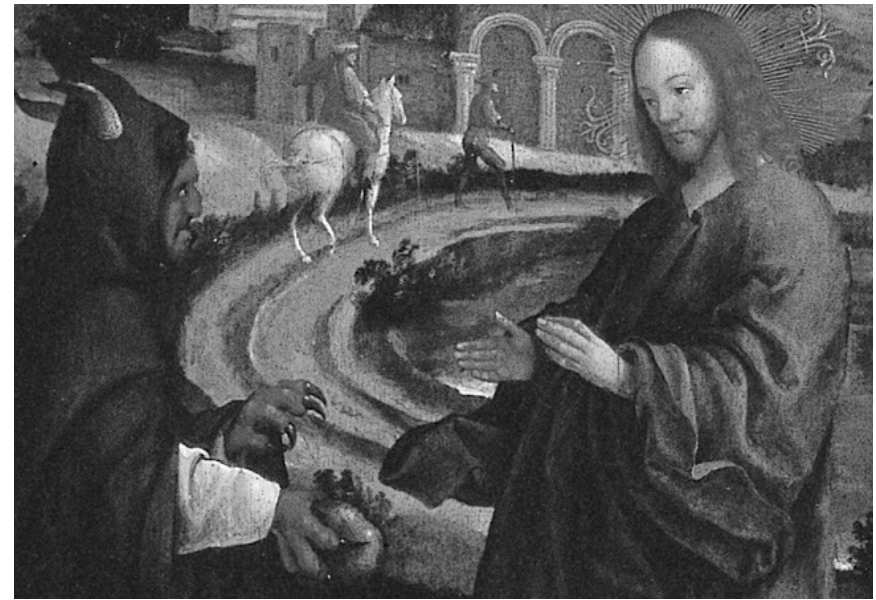

Рис. 6. Фрагмент картины Якоба Корнелиса ван Остзанена «Искушение Христа в пустыне» (1530 год)

ников-учёных 15 века «Пятнадцать сконструированных фигур и голов» Альбрехта Дюрера и «Тетрадей по анатомии» Леонардо да Винчи можно детально изучать и анализировать все особенности лица человека после выполненной хирургической коррекции: значительное нарушение симметрии и гармонии лица, опущение и уплощение кончика носа, практически полное отсутствие верхней губы, значимое недоразвитие верхней челюсти и средней зоны лица, а нижняя челюсть кажется чрезмерно развитой на фоне врождённой гипоплазии верхней челюсти [13].

Полотно голландского живописца Якоба Корнелиса ван Остзанена «Искушение Христа в пустыне» изображает дьявола одетого в капюшон монаха с лицом, совершенно ясно выражающим проведённую хирургическую коррекцию врождённой расщелины лица (рис. 6).

В искусстве Средних веков и раннего Возрождения можно найти много свидетельств самых разных персонажей, по той или иной причине изображенных с расщелиной лица: военных, палачей, оруженосцев, а также персонажей различных библейских сюжетов.

Более современное отражение врождённого дефекта челюстно-лицевой области можно найти на полотне Поля Сезанна «Пирамида из черепов», на которой на двух черепах из четырёх присутствует расщелина альвеолярного отростка и нёба (рис. 7). Идея создания данной работы, как полагают исследователи творчества Сезанна, тесно связана с антропологическими находками Рудольфа Вирхова и проведёнными им палеонтологическими исследованиями черепов, найденных учё- 


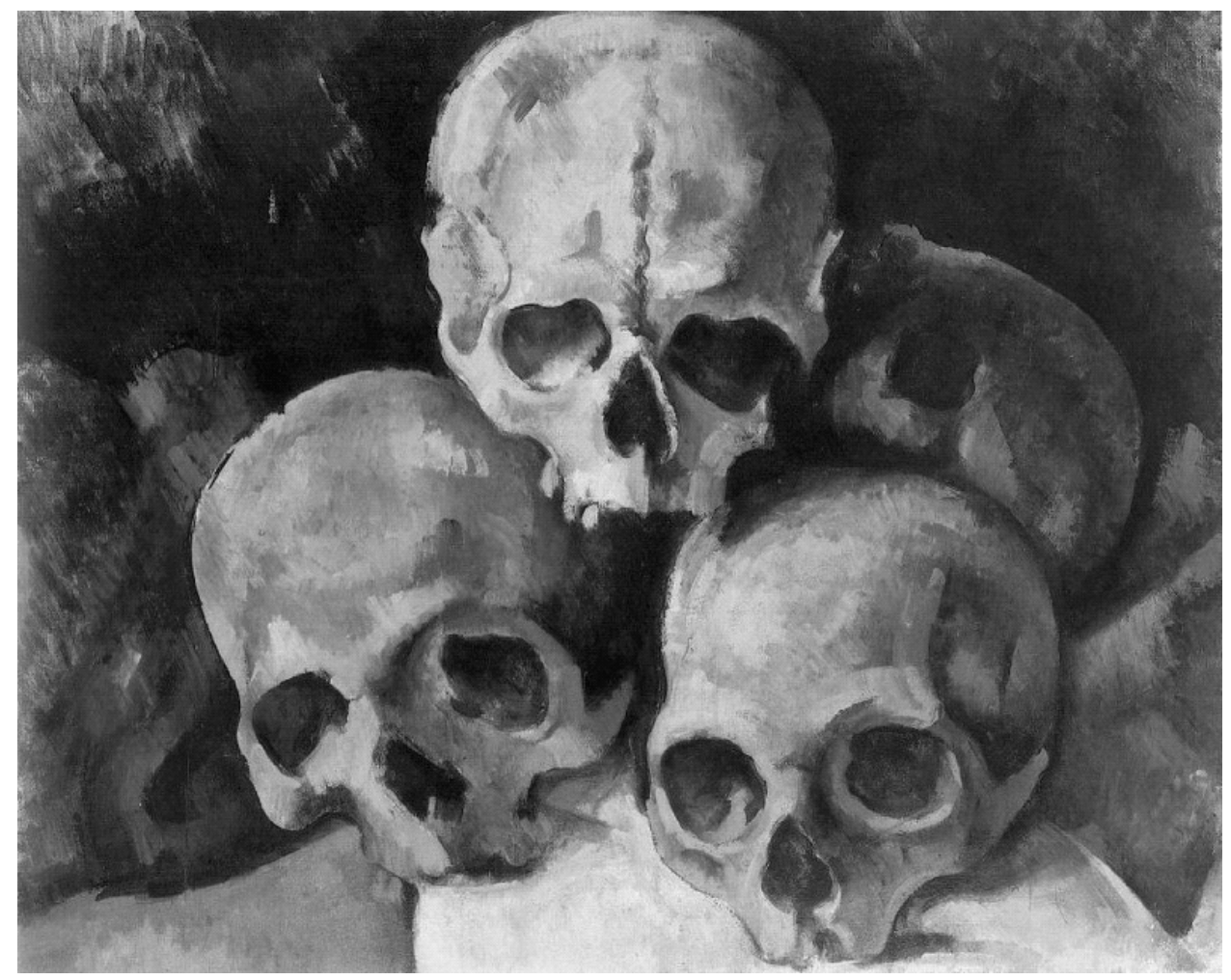

Рис. 7. «Пирамида из черепов» Поль Сезанн (1901 год)

ным при раскопках в Перу, которые имели врождённые дефекты различных локализаций [14].

\section{Распространённость вро» расшелин миша в мире}

Изолированная врождённая расщелина лица главенствует среди всех пороков развития человека, занимая первое место по всему миру среди пороков развития челюстно-лицевой области, и второе место - среди всех пороков развития человека, затрагивая 1\%-2\% новорождённых по всему миру с фатальной вероятностью увеличения риска её возникновения в зависимости от географического происхождения и этнической группы. Согласно последним общемировым статистическим данным, популяции восточной Азии, коренных Американцев и североевропейских стран имеют наибольшую частоту развития врождённых расщелин лица, в то время как этнический состав народов Африки - наименьший [8]. Несмотря на вовлеченность множества ключевых генов, риски частичного наследования врождённой расщелины, влияние самых различных эпигенетических факторов на 5-12 недели развития эмбриона остаётся зачастую предопределяющим.

К принципиальным эпигенетическим факторам высокого риска развития пороков лица и аномалий других органов относится тератогенное воздействие различных вирусов в антенатальный период, наиболее частыми из которых - вирус гриппа А и В, вирус герпеса, вирус кори и других. По последним зарубежным данным, пандемия новой коронавирусной инфекции COVID-19 значительно усугубило течение родов и ранний послеродовой период у инфицированных женщин [12].

История создания и современное состояние организации междисциплинарной помощи детям с врождёнными аномалиями и деформациями челюстно-лицевой области в специализированном диспансерном центре Санкт-Петербурга

В 1970 году 22 мая приказом Здравоохранения № 291 в Ленинграде открылся уникальный высокоспециализированный медицинский центр комплексной помощи детям с аномалиями развития тканей челюстно-лицевой области. В этом же году согласно приказу МЗ РСФСР № 175 от 16.07.1970 Центр приобрел юридический статус центра диспансерного наблюдения за детьми с аномалиями развития тканей челюстно-лицевой области Северо-Западного региона [3]. Идеологом создания Центра выступил выдающийся челюстно-лицевой хирург членкорр. РАН профессор В.А. Козлов (рис. 8) и талантливый врач д.м.н. И.С. Рубежова (рис. 9), организовавшая и руководившая всеми ортодонтическими и ортопедически- 


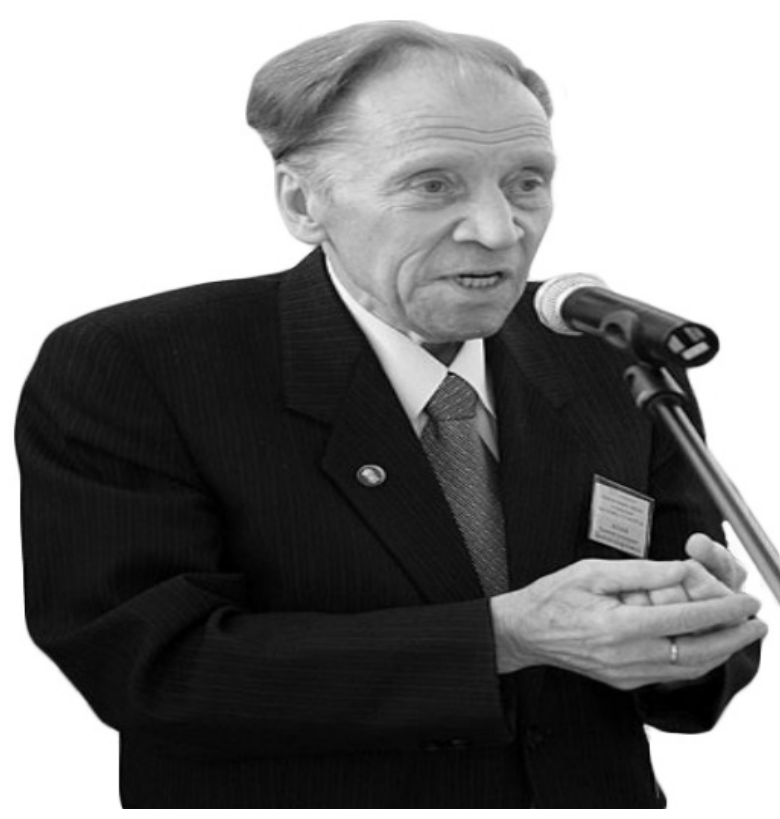

Рис. 8. Челюстно-лицевой хирург профессор член-корр. РАН Владимир

Александрович Козлов

ми этапами сложного комплексного лечения детей с расщелинами лица. Отечественной школой блистательных челюстно-лицевых хирургов профессором член-корреспондентом АМН СССР А. А. Лимбергом, В.И. Знаменским и Г.А. Котовым совместно с врачами-ортодонтами к.м.н. Е.Д. Лалетиной, д.м.н. И.С. Рубежовой, к.м.н. Н.И. Ярчук, 3.И. Часовской, к.м.н. Э.Е. Слободник и др. был заложен фундамент комплексной медицинской реабилитации детей с врождёнными расщелинами лица с момента рождения до совершеннолетия [2].

На протяжении 50 лет единственный специализированный центр Санкт-Петербурга оказывает стоматологическую помощь детям с подключением специалистов междисциплинарных областей: стоматологов всех специализаций, генетика, ЛОР-врача, логопеда, психолога и психотерапевта у детей с врождёнными расщелинами лица, а также у детей с редкими сочетанными и изолированными врождёнными пороками и синдромами развития лица (синдром 1-2 жаберных дуг, синдром Горлина-Гольца, синдром Крузона и многих других). Специалисты Центра проводят комплексную реабилитацию пациентов после травм челюстно-лицевой области, удаления новообразований, а также реабилитацию детей после воспалительно-инфекционных заболеваний.

Ежегодно 300-350 первичных пациентов с врождёнными аномалиями развития тканей челюстно-лицевой области поступают в Центр на учёт и проходят междисциплинарное лечение, включающее ортодонтическое

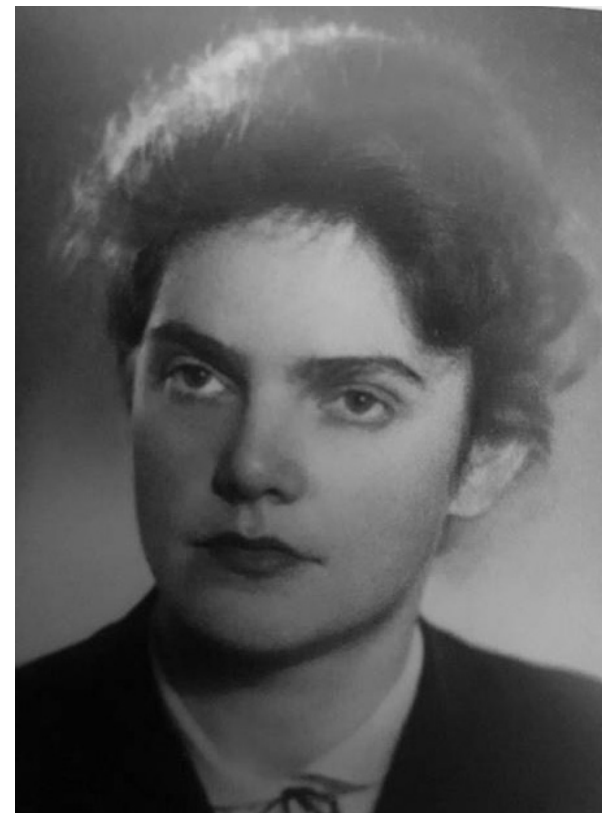

Рис. 9. Врач-ортодонт профессор д.м.н. Инна Семеновна Рубежова

и ортопедическое лечение, логопедическую подготовку, лечение в кабинете стоматолога-терапевта, наблюдение у челюстно-лицевого хирурга, а также ЛОР-врача.

За период функционирования Центра был разработан прерогативный алгоритм ведения детей с врождёнными расщелинами лица. При рождении ребёнка с расщелиной лица из роддома или больницы в колл-центр поступает заявка от врача родильного отделения и врач Центра в обязательном порядке заносит вызов в специальный регистрационный журнал, в котором фиксирует форму расщелины лица, параметры новорождённого, особенности питания ребёнка (соска-рожок, посредством назогастрального или орогастрального зонда), сопутствующие патологии. Врачи Центра осуществляют выезд во все детские городские больницы и родильные дома Санкт-Петербурга и области. При орогастральном питании новорожденного в подавляющем большинстве случаев образуется пролежень, который при изготовлении протеза нёба и гигиенической обработке данной области слизистой нёба полностью устраняются через 4-5 дней. Восстановление функций питания, глотания и дыхания, а значит набор веса младенца при помощи изготовления индивидуального протеза нёба сокращает сроки нахождения мамы и ребенка в больнице, что, кроме того, сокращает затраты здравоохранения. В отечественной школе ортодонтии был заложен принцип, который успешно внедрён и используется до сих пор в специализированном диспансерном центре, основу которого составляет изготовление полностью ин- 
дивидуального ортопедического аппарата - протеза нёба для восстановления функций питания, глотания и дыхания новорождённого, а также с целью нормализации аномалийной с рождения формы верхней челюсти перед первичной хейлоринопластикой [1, 4]. Таким образом, оказание ранней медицинской реабилитации пациентам с врождёнными расщелинами лица - ценный медицинский и значимый психологический ресурс качественного лечения и восстановления не только для маленьких пациентов, но и родителей пациента $[9,11]$.

В диспансерном центре Санкт-Петербурга была разработана программа дородового консультирования женщин, целью которой является психологическая адаптация самой женщины к рождению ребёнка с врождённой расщелиной лица и особенностям ухода за ним. На этапе подготовки к родам в диспансерном центре женщина получает медико-генетическую консультацию, целью которой является описание молекулярно-генетического «портрета» родителей, а также определение в процессе скрининга молекулярного фенотипа у ребёнка.

Работа выполнена при финансовой поддержки федерального гранта Президента Российской Федерации МK-2288.2020.7. для материальной поддержки молодых российских ученых - кандидатов наук и докторов наук в 2020-2021 годах.

\section{ЛИТЕРАТУРА}

1. Междисциплинарный подход к лечению пациентов с двухсторонней расщелиной губы и нёба / Ж. А. Блиндер, А. А. Мамедов, Ю. И. Кучеров и др. // Медицинский алфавит. - 2016. - № 2.- С. 48-51.

2. Рубежова, И. С. Этапы и объем комплексного лечения детей с различными формами врожденных расщелин верхней губы и неба в Санкт-Петербургском диспансерном центре / И. С. Рубежова, Э. С. Керод, М. Б. Трушко // Материалы II международной конференции челюстно-лицевых хирургов.— 2002.— № 4. - C. 41-42.

3. Силин, А. В. Кабинет, кафедра, факультет. Исторический очерк ос стоматологии / А. В. Силин.—СПб.: Человек, 2011. - 78 с.

4. Чернобровкина, М. И. Антропометрическая оценка пациентов с односторонней врождённой расщелиной верхней губы и нёба / М.И. Чернобровкина, А. В. Силин, С. Л. Плавинский // Вестник СЗГМУ.— 2016. - Том. 8. — № 4.- С. 27-37.

5. Carod-Artal, F.J. Evidence of facial palsy and facial malformations in pottery from Peruvian Moche and Lambayeque pre-Columbian cultures / F. J. Carod-Artal, C. B. Cabrera // Neurologia.—2006.— № 21.—P. 297-303.

6. Cleft Lip and Palate in the Arts: A Critical Reflection / M. Saman, J. Gross, A. Ovchinsky et al. // Cleft Palate-Craniofacial Journal.—2012.— № 2.—P. 129-136.

7. Foundation-Based Cleft Care in Developing Countries / R. S. Kantar, M. J. Cammarata, W. J. Rifkin et al. // Plast Reconstr Surg J. Cleft Palate. — 2019.— № 143.— P. 1165-1178.

8. Gallagher, N.A general dental practitioner's role in treating patients with a cleft lip and/or palate / N. Gallagher // British Dental Journal.— 2020.— № 228.— P. 19-21.

9. Hardwicke, J. Reporting of Randomized Controlled Trials in Cleft Lip and Palate: A 10-Year Review / J. Hardwicke, M. Nassinizadeh, B. Richard // Cleft Palate Craniofac J.— 2017.— № 54.—P. 142-152.

10. Hwang, K. Masks depicting hemifacial microsomia and cleft lip / K. Hwang, R. S. Chung // J Craniofac Surg. — 2002. — № 13.—P. $721-723$.

11. Infant orthopedics and facial growth in complete unilateral cleft lip and palate until six years of age (Dutchcleft) / C. A. Bongaarts, B. Prahl-Andersen, E. M. Bronkhorst et al. // Cleft Palate Craniofac J.— 2009.— № 46.—P. 654-663.

12. Liang, H. Novel corona virus disease (COVID-19) in pregnancy: What clinical recommendations to follow? / H. Liang, G. Acharya // Acta Obstet Gynecol Scand. 2020. — № 99.—P. 439-442.

13. Pirsig, W. Surgically repaired cleft lips depicted in paintings of the late Gothic period and the Renaissance / W. Pirsig, S. Hasse, F. Palm // Br J Oral Max Surg.2001. — № 39.—P. 127-133.

14. Seemann, S. The Base of the Skull. Rudolf Virchow between Pathology and Anthropology / S. Seemann // Medizinhist J.— 2016.— № 51.—P. 92-123.

15. Stasiak, M. Current methods for secondary alveolar bone grafting assessment in cleft lip and palate patients - A systematic review / M. Stasiak, A. WojtaszekSłomińska, B. Racka-Pilszak // J Craniomaxillofac Surg. — 2019.— № 47.—P. 578-585.

16. Stock, N. M. Delivering effective genetic services for patients and families affected by cleft lip and/or palate / N. M. Stock, R. MacLeod, J. Clayton-Smith // Eur J Hum Genet.—2019.— № 25.—P. 1-8.

() Чернобровкина Мария Игоревна ( tchernobrovik@mail.ru ), Силин Алексей Викторович ( silin@me.com ).

Журнал «Современная наука: актуальные проблемы теории и практики» 